\title{
Edirne İli Barajlarının Bazı Fiziko-Kimyasal Özellikleri ve Sulama Suyu Kalite Sınıfları
}

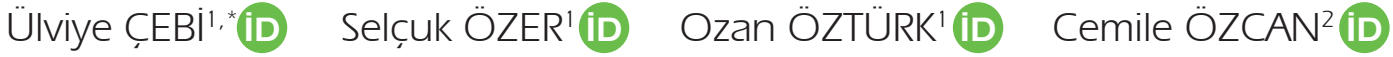 \\ Ezgi TOK ${ }^{3}$ iD Bülent ȘENGÖRÜR ${ }^{4}$ (iD) Yeșim AHi (D)

\begin{abstract}
'Atatürk Toprak Su ve Tarımsal Meteoroloji Araștırma Enstitüsü Müdürlüğü, Kırklareli
${ }^{2}$ Kırklareli Üniversitesi, Fen Edebiyat Fakültesi, Kimya Bölümü, Kırklareli

${ }^{3}$ Kırklareli Üniversitesi, Mimarlık Fakültesi, Șehir Bölge Planlama Bölümü, Kırklareli,

${ }^{4}$ Kırklareli Üniversitesi, Mühendislik Fakültesi, İnșaat Mühendisliği Bölümü, Kırklareli

${ }^{5}$ Namık Kemal Üniversitesi, Biyosistem Mühendisliği Bölümü, Tekirdağ
\end{abstract}

*Sorumlu yazar e-mail (Corresponding author e-mail): ulviyecebi@yahoo.com

Geliș tarihi (Received) : 18.04.2019

Kabul tarihi (Accepted): 05.08.2019

DOI: $10.21657 /$ topraksu. 555554

\section{Öz}

Tüm Dünya'nın güncel sorunu olan su kirliliği Trakya Bölgesinde de sanayileșme, kentleșme ve nüfus artıșıyla paralel olarak artmıș ve hızla artmaya devam etmektedir. Aynı zamanda yoğun ve denetimsiz su tüketimi Trakya Bölgesindeki yer altı ve yer üstü su kaynaklarının günden güne azalmasına neden olmaktadır. Sulamada kullanılan suların kalitesinin bilinmesi, bitki yetiștiriciliği ve ileriye dönük toprakta olușabilecek problemlerin önüne geçilebilmesi için önemli bir göstergedir. Bu çalıșmada, Edirne ilinde, ișletmedeki 4 adet baraj ele alınmıș ve sulama suyu açısından uygunluğu belirlenmiștir. Elde edilen sonuçlara göre; Süloğlu barajı $T_{1} A_{1}$ ve $T_{2} A_{1}$, Altınyazı barajı $T_{2} A_{1}$, Sultanköy barajı $T_{2} A_{1}$ ve Hamzadere barajı $T_{3} A_{1}$ sulama suyu sınıfında yer almıștır. Kıtaiçi yerüstü su kaynaklarının sınıflarına göre barajların kalite kriterleri irdelendiğinde, Süloğlu, Sultanköy ve Hamzadere barajları II ve III sınıfta, Altınyazı barajı II. sınıfta yer almıștır. FAO-29 sınıflamasına göre, Süloğlu, Sultanköy ve Altınyazı barajları genelde I. sınıfta yer alırken, Hamzadere barajı birçok parametre açısından II. sınıfta yer almıștır.

Anahtar kelimeler: Edirne, baraj, sulama, su kalitesi

\section{Some Physical-Chemical Characteristics and Irrigation Water Quality Classes of the Dams in Edirne Province}

\begin{abstract}
Water pollution which is the daily problem of the whole world has increased in parallel with industrialization, urbanization and population, and it is increasing rapidly. At the same time, intensive and uncontrolled water consumption causes the decline of underground and over ground water resources day by day in Thrace Region. Having information about the quality of the water used in the irrigation is a significant indicator in order to prevent the problems in the soil. In this study, 4 dams in Edirne province were handled and convenience of the dams in terms of irrigation water was determined. According to the results, Süloğlu dam was in $T_{1} A_{1}$ and $T_{2} A_{1}$ irrigation water class. Altınyazı dam, Sultanköy dam and Hamzadere dam were in $T_{3} A_{1}$ irrigation water class. When the quality criteria of the dams were examined according to the intra-continental ground water sources classes, it was determined that Süloğlu dam, Sultanköy dam and Hamzadere dam were in II and III classes and Altınyazı dam was in the II class. According to FAO-29 classification, Süloğlu, Sultanköy and Altınyazı dams were generally in I the class and Hamzadere dam was in the II class in terms of many parameters.
\end{abstract}

Key words: Edirne, dam, irrigation, water quality 


\section{Giriș}

Son yıllarda insan faaliyetleri sonucunda, doğal olarak binlerce yıldan beri ekosistemlere hayat veren yer üstü ve yer altı su kaynakları; enerji üretimi, endüstri, içme ve kullanma ile tarımda sulama amaçlı olarak yoğun șekilde tüketilmektedir. Gelișmișliğin de göstergesi olan kiși bașına su tüketimi günden güne artmaktadır. Bu nedenle de yer altı ve yerüstü su kaynakları zamanla azalmaktadır. Endüstriyel atıklar, tarımda gübre ve ilaç kullanımı, evsel atıklar, yer üstü ve yer altı sularının kalitesini büyük ölçüde yok ederek, sulardaki canlı hayatın yanı sıra toprağı ve çevreyi de olumsuz yönde etkilemektedir.

Tüm dünyanın güncel sorunu olan su kirliliği Trakya Bölgesi'nde de sanayileșme, kentleșme ve nüfus artıșıyla paralel olarak artmıș ve hızla artmaya da devam etmektedir (Çebi vd., 2008). Aynı zamanda yoğun ve denetimsiz su tüketimi Bölgemizdeki yer altı ve yer üstü su kaynaklarının günden güne azalmasına neden olmaktadır (İstanbulluoğlu vd., 2006).

Edirne ilinde yer alan Altınyazı, Süloğlu ve Sultanköy baraj sularının kalitesini belirlemeye yönelik yapılan çalıșmada (Tokatlı, 2018) her üç barajda $\mathrm{NO}_{2}$, fekal koliform kirliliği belirlenirken, Sultanköy ve Süloğlu barajlarında biyolojik oksijen intiyacı $\left(\mathrm{BOI}_{5}\right)$ değerleri yüksek bulunmuștur. Süloğlu barajında, yaz aylarında $\mathrm{pH}$ değerleri 8.51 ile 9.04 arasında, nitrat azotu $\left(\mathrm{NO}_{3}-\mathrm{N}\right)$ değerleri yıl boyunca 0.00 ile $4.23 \mathrm{mg} \mathrm{L}^{-1}$ arasında bulunurken, BOI5 kirliliği belirlenmemiștir (Karaca, 2015). Trakya Bölgesi'nde plansız ve kontrolsüz sanayileșmenin yaratığı en büyük su kirliliğine örnek Ergene Nehri'dir. Ergene Nehri suyu ylllarca incelenmiș ve incelenmeye de devam edilmektedir. Gidirișlioğlu vd. (1996)'ne göre Ergene Nehri suyu yüksek düzeyde kirlilik parametreleri (EC-elektriksel iletkenlik, KOikimyasal oksijen intiyacı, RSC-artık sodyum karbonat, Cl-klor) içermektedir ve sulama suyu olarak kullanılmamalıdır. Benzer sonuçlar 20052007 yılları arasında yürütülen (Çebi vd., 2008) çalıșmada da elde edilmiș olup, Ergene Nehri suyunun kesinlikle sulama amaçlı kullanılmaması gerektiğini ortaya koymuștur. Çalıșmada nehir suyunda $\mathrm{Ni}, \mathrm{Fe}, \mathrm{Cr}$, Cd ve $\mathrm{Zn}$ gibi ağır metaller de tespit edilmiștir. Nehir suyunun sulama suyu olarak kullanılması durumunda ayçiçeği bitkisinin vejetatif gelișmesinin olumsuz yönde etkilendiği gözlenmiștir (Çakır ve Gidirișlioğlu, 1997; Çakır vd., 1997). Bir bașka çalıșmada ise Ergene suyu ile sulanan topraklarda ekilen tohumun çimlenmesi ve çıkıș süreleri uzamıș, bitkilerin boy ve yaprak sayısı gibi bitki vejetatif aksamlarının gelișmesinde olumsuz etkiler gözlenmiștir (Konukçu vd., 2004). Kirlenmiș olan Ergene suyunun çok ama çok kontrollü bir șekilde tarımda sulama amaçlı kullanılması gerektiği ortaya konulmuștur (Konukçu vd., 2004). Bölgede (Tekirdağ ili) 73 içme suyu kuyusunda yapılan nitrat, amonyum ve tuzluluk analizlerinde, tüm kuyularda amonyum azotu belirlenmiș olup, nitrat seviyelerinin 6'sı tavsiye edilebilir, 2 tanesi müsaade edilebilir doz değerlerinin üzerinde çıkmıștır. EC değerlerinin \%30'undan fazlası iyi bir içme suyunda müsaade edilebilir değerlerden daha yüksek EC'ye sahip olduğu belirlenmiștir (Katkat vd., 1997). Ergene Havzasında 51 adet sondaj kuyusundan alınan su örneklerinde tuzluluk değerleri $256 \mu \mathrm{M} \mathrm{cm}^{-1}$ ile $1295 \mathrm{HS} \mathrm{cm}^{-1}$ arasında belirlenirken kuyularda Fe miktarı 0.01-0.25 $\mathrm{mg} \mathrm{L}^{-1}$, Silis miktarı ise 2.2$43.9 \mathrm{mg} \mathrm{L}^{-1}$ aralığında bulunmuștur (Kaykığlu ve Ekmekyapar, 2005). İstanbulluoğlu vd. (2006)'ne göre, Trakya Bölgesi Türkiye'de kiși bașına düșen su miktarının en az olduğu bölge olup, kısıtlı su kaynaklarının bölgenin intiyaçları dikkate alınarak sektörel dağılımı içeren bir planlama, geliștirme, izleme ve değerlendirme çalıșmalarından yoksundur. Bu durum su kaynaklarını tehdit ederek, gıda güvenliğine ve ekonomik gelișmelere gölge düșürmekte, ayrıca ülke istikrarında büyük öneme sahip tarım sektörü içindeki sulu tarımı da derinden etkilemektedir.

Günümüzde sulama suyu niteliği, yeterli suyun sağlanması kadar önemli bir sorun olușturmaktadır. Zira modern sulama yöntemleri ne kadar iyi kullanıırsa kullanılsın, sulamada uygun kaliteli su kullanılmadığı zaman ürün miktarı ve kalite düșer, toprakta kısa süre içinde tuzlulașmaçoraklașma sorunu bașlar. Bu çalıșmada, Edirne ilinde yer alan ve tarımsal sulama amaçlı kullanılan Süloğlu, Altınyazı, Sultanköy ve Hamzadere baraj sularının sınıflamasında esas alınan sulama suyu kalite parametreleri bakımından karakterizasyonu yapılmıș, ayrıca besin elementleri $\left(\mathrm{NH}^{+}{ }_{4}, \mathrm{NO}_{3}\right.$ ve P) ve iz elementleri ile inorganik kirlilik parametreleri açısından irdelenmiștir. 


\section{MATERYAL VE YÖNTEM}

\section{Materyal}

Trakya Bölgesi hizmet alanı içinde 14560 km² yüzölçümü ile Meriç-Ergene Havzası ve 4105 km² yüzölçümü ile Kuzey Marmara Havzası bulunmaktadır. Türkiye'de yıllık ortalama yağıș miktarının 643 mm olduğu düșünüldüğünde Bölgemizin yağıș ortalaması $621 \mathrm{~mm}$ ile ülke ortalamasının altında kalmaktadır (DSi, 2019).

Çizelge 1. Edirne ilinde incelemeye alınan barajlar ve özellikleri

Table 1. The dams in Edirne province and the characteristics

\begin{tabular}{|c|c|c|c|}
\hline Barajlar & Barajın Yeri & Amacı & Toplam Sulama Alanı (ha) \\
\hline Süloğlu & $\begin{array}{l}\text { Edirne ilinin } 36 \text { km kuzeydoğusunda, Süloğlu } \\
\text { ilçesine } 2.5 \text { km mesafede }\end{array}$ & $\begin{array}{c}\text { Sulama, } \\
\text { Tașkın koruma }\end{array}$ & 4009 \\
\hline Altınyazı & $\begin{array}{c}\text { Edirne ili Altınyazı Kasabasının yaklașık } 1 \text { km } \\
\text { kuzeydoğusunda }\end{array}$ & $\begin{array}{l}\text { Sulama, } \\
\text { Tașkın koruma }\end{array}$ & 7524 \\
\hline Sultanköy & Edirne ili, İpsala ilçesine 16 km mesafede & Sulama & 7773 \\
\hline Hamzadere & $\begin{array}{c}\text { Edirne ili İpsala ilçesi Koyuntepe köyünün } 3 \\
\text { km doğusunda }\end{array}$ & Sulama & 33564 \\
\hline
\end{tabular}

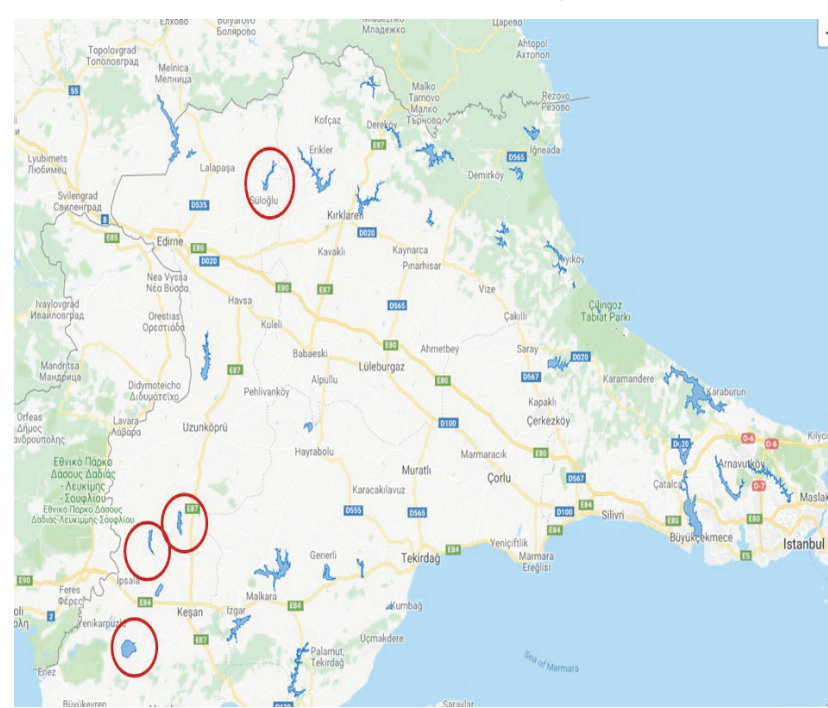

Șekil 1. Edirne ilinde örnekleme yapılan barajlar Figure 1. The sampling points in Edirne province

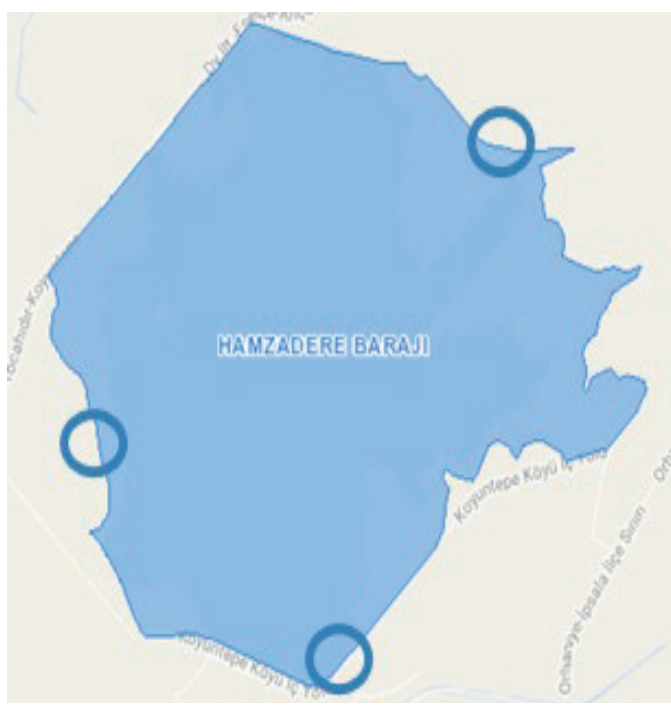

Șekil 2. Hamzadere barajı örnekleme noktaları Figure 2. Hamzadere dam sampling points

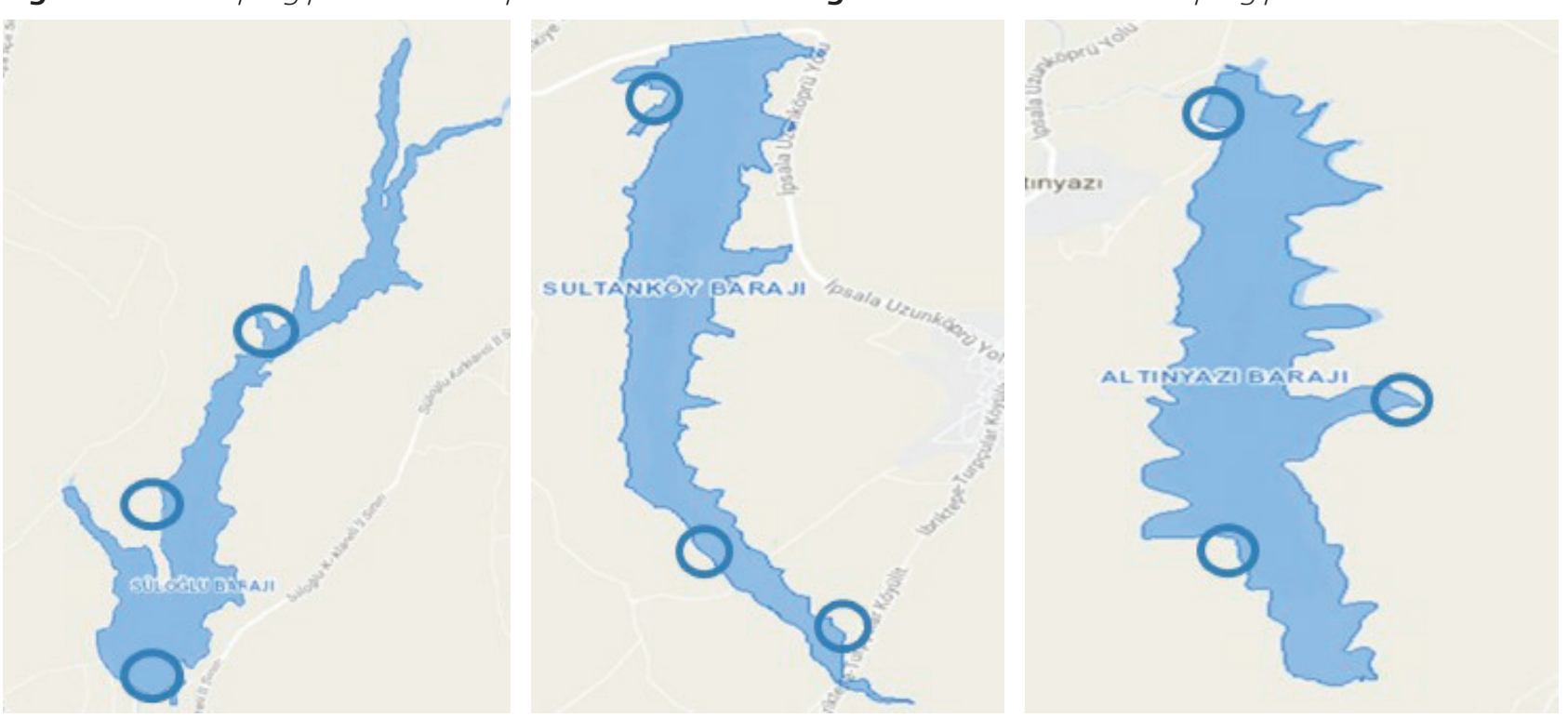

Șekil 3. Süloğlu, Sultanköy ve Altınyazı barajları örnekleme noktaları

Figure 3. Süloğlu, Sultanköy and Altınyazı dams sampling points 
Bölgemizde 1.239 milyon ha tarıma elverișli arazi ile Türkiye'nin \%4'ünü, 1.047 milyon ha sulanabilir arazi ile de Türkiye'nin yine \%4'ünü teșkil etmektedir (DSi, 2019). Ekonomik olarak sulanabilir arazi ise 413388 ha'dır. 98 milyar m3'lük Türkiye yerüstü su potansiyelinin \% 9.65'i olan 9461 milyar m3'ü Trakya Bölgesi yer üstü su potansiyelini teșkil etmektedir. Ancak Bölge yer üstü su potansiyelinin 5842 milyar $m^{3}$ 'ü Yunanistan'la sınır teșkil eden Meriç Nehri'nden kaynaklanmaktadır. 14 milyar $\mathrm{m}^{3}$ lük Türkiye yer altı su potansiyelinin \% 3.16'sı olan 0.460 milyar $\mathrm{m}^{3 \prime} \mathrm{u}$ Bölgemiz yeraltı su potansiyelini teșkil etmektedir (DSi, 2019).

Edirne ili toplamda 7611 hm3 yer üstü su potansiyeline sahip olup bunun $611 \mathrm{hm}^{31} \mathrm{ü} \mathrm{kendi}$ havzasından, 5842 hm3'ü Meriç nehri sınır giriși ve $1158 \mathrm{hm}^{3}$ 'ü Meriç, Yunanistan kesiminden gelmektedir. İlin yer altı su potansiyeli $168 \mathrm{hm}^{3}$ tür. Sulanabilir arazi varlığı 417934 ha iken, ekonomik olarak sulanan arazi 245757 ha'dır.

Çalıșmada incelemeye alınan barajlara ait bazı bilgiler Çizelge 1'de ve barajların bölgedeki konumu ile örnek alma noktaları șekil 1, Șekil 2 ve Șekil 3'te verilmiștir.

\section{Yöntem}

Su örnekleri, suyun baraja giriș ve çıkıș noktaları ile baraj kıyılarındaki faaliyetlerin su kalitesine etkileri de dikkate alınarak bütün su kütlesindeki kalite değișimini karakterize edecek șekilde, üç noktadan "Su Kirliliği Kontrolü Yönetmeliği Numune Alma ve Analiz Metotları Tebliğine" (Anonim, 2009) uygun olarak alınmıștır. Örneklemeler ayda bir kez olmak üzere 2016 yılı sulama mevsimi boyunca yapılımıștır (Haziran, Temmuz, Ağustos Eylül ve Ekim aylarında).

Su örneklerinde, $\mathrm{pH}, \mathrm{EC}$ (elektriksel iletkenlik), TDS (toplam çözünmüșiyonlar) ve ORP (oksidasyonredüksiyon potansiyeli) gibi analizler Aduaread AP-800 multimetre cihazı kullanılarak yerinde yapılmıștır. Her okuma öncesi cihaz kalibrasyonu standart çözeltiler kullanılarak yapıımıș $(\mathrm{pH}$ için: buffer sol. $\mathrm{pH}=4$, $\mathrm{pH}=7$ ile $\mathrm{pH}=10$; $E C$ için $\mathrm{RC}-600$ rapit cal. sol. Aduaread; TDS için formazin turbidty std. Form. 100005; ORP için RC-600 rapit cal. sol. aquareed), $\mathrm{pH}$ ve EC parametrelerin ölçümü laboratuvar șartlarında tekrarlanmıștır.

\section{Anyonlar}

Klorür $(\mathrm{Cl})$, sülfat $\left(\mathrm{SO}_{4}^{-2}\right), \quad$ amonyum azotu $\left(\mathrm{NH}_{4}-\mathrm{N}\right)$ ve nitrat azotu $\left(\mathrm{NO}_{3}-\mathrm{N}\right)$ lon Chromatographic Metoda göre, toplam fosfor ise Standart Metot-3500 göre, ICP ile yapılmıștır.

\section{Katyonlar}

Na, Ca, Mg, K- Standart Metot-3500'e göre ICP ile, karbonat $\left(\mathrm{CO}_{3}\right)$, ve bikarbonat $\left(\mathrm{HCO}_{3}\right)$ Tüzüner (1990)'in belirtmiș olduğu esaslara göre belirlenmiștir.

\section{İz elementleri (metaller) ve inorganik kirlilik parametreleri}

Civa $(\mathrm{Hg})$, arsenik (As), ve selenyum (Se) Standart Metot- 3500-Inductively Coupled Plasma, hidrür sistemi kullanılarak, kadminyum $(\mathrm{Cd})$, kurșun $(\mathrm{Pb})$, bakır $(\mathrm{Cu})$, krom $(\mathrm{Cr})$, kobalt (Co), nikel (Ni), çinko (Zn), demir (Fe), mangan (Mn), bor (B) ve alüminyum (Al) Standart Metot3500-Inductively Coupled Plasma Metoduna göre yapılmıștır (Andrew, 1995).

\section{Analiz ve değerlendirme}

Analizlerin her biri üç tekrarlamalı olarak yapılmıș, SCP SCIENCE standart yerüstü su örnekleri ile standardizasyonu yapıımıștır. Sonuçlar Su Kirliliği Kontrol Yönetmeliğinde yer alan Kıtaiçi Yerüstü Su Kaynaklarının Sınıflarına Göre Kalite Kriterleri (Anonim, 2015) kapsamında belirlenmiș ve sınıflandırılmıștır. Bu sınıflamanın yanı sıra, Atıksu Arıtma Tesisleri Teknik Usuller Tebliğinde sulama suyunun kimyasal kalitesinin değerlendirilmesi için geliștirilmiș tabloda (Anonim, 2010) yer alan kalite parametreleri esas alınarak suların, sulama sınıfları belirlenmiștir.

Elde edilen sonuçlar, ayrıca FAO-29 (1994)'da yer alan kalite parametreleri de dikkate alınarak sınıflama yapılmıștır. Suların, sulama suyu sınıfının belirlenmesinde U.S. Salinity Lab. Staff, 1969 diyagramı kullanılmıștır.

\section{BULGULAR VE TARTIȘMA}

Haziran-Ekim 2016 dönemlerinde su kalitesi izlemesi yapılan Süloğlu baraj sularının kalite parametreleri Çizelge 2'de verilmiștir. Çizelgelerde yer alan verilere göre; baraj suyu, sulama suyu açısından $T_{2} A_{1}$ ve $T_{1} A_{1}$ sınıfında yer almıștır. Bu sınıflamaya göre $T_{1}$-az tuzlu, $T_{2}$-orta tuzlu su ve $A_{1}$-az sodyumlu su sınıfında yer almıș olup, gerek tuzluluk gerek alkalilik bakımından değișik topraklarda ve çeșitli bitkilerde sulama suyu olarak kullanılabilir su sınıfında yer almıștır. Sulama suların kalitesini belirlemede kullanılan bir diğer parametre RSC (artık sodyum karbonat)'dir. Baraj sularında artık sodyum karbonat tespit edilmemiștir. 
Çizelge 2. Süloğlu barajı aylık analiz sonuçları

Table 2. Monthly analysis results of Süloğlu dam

\begin{tabular}{|c|c|c|c|c|c|c|c|}
\hline Parametreler & $\begin{array}{c}\text { Haziran } \\
2016 \\
\end{array}$ & $\begin{array}{c}\text { Temmuz } \\
2016 \\
\end{array}$ & $\begin{array}{c}\text { Ağustos } \\
2016\end{array}$ & $\begin{array}{l}\text { Eylül } \\
2016 \\
\end{array}$ & $\begin{array}{l}\text { Ekim } \\
2016 \\
\end{array}$ & SSKK & FAO-29 \\
\hline $\mathrm{pH}$ & 8.69 & 8.49 & 8.50 & 8.50 & 8.31 & & \\
\hline İletkenlik (dS $\mathrm{m}^{-1}$ ) & 0.261 & 0.279 & 0.252 & 0.257 & 0.243 & 1 & I \\
\hline $\mathrm{co3}^{-2}\left(\mathrm{me} \mathrm{L}^{-1}\right)$ & 0.9 & 1.01 & 0.9 & 0.58 & 0.34 & & \\
\hline HCO3- $\left(\mathrm{me} \mathrm{L}^{-1}\right)$ & 1.3 & 1.45 & 1.45 & 2.03 & 1.66 & & $\|^{*}$ \\
\hline $\mathrm{Cl}^{-}\left(\mathrm{me} \mathrm{L}^{-1}\right)$ & 0.55 & 0.45 & 0.55 & 0.45 & 0.97 & I & I \\
\hline $\mathrm{Na}^{+}\left(\mathrm{me} \mathrm{L}^{-1}\right)$ & 0.64 & 0.62 & 0.63 & 0.68 & 0.61 & I & I \\
\hline $\mathrm{Mg}^{+2}\left(\mathrm{me} \mathrm{L}^{-1}\right)$ & 0.76 & 1.01 & 0.86 & 0.89 & 0.83 & & \\
\hline $\mathrm{K}^{+}\left(\mathrm{me} \mathrm{L}^{-1}\right)$ & 0.09 & 0.11 & 0.09 & 0.04 & 0.09 & & \\
\hline $\mathrm{Ca}^{+2}\left(\mathrm{me} \mathrm{L}^{-1}\right)$ & 1.53 & 1.52 & 1.43 & 1.56 & 1.49 & & \\
\hline SAR & 0.6 & 0.55 & 0.6 & 0.62 & 0.57 & I & I \\
\hline $\mathrm{SO}_{4}\left(\mathrm{me} \mathrm{L}^{-1}\right)$ & 0.27 & 0.35 & 0.11 & 0.11 & 0.05 & & \\
\hline RSC & - & - & - & - & - & & \\
\hline Sertlik (Alman) & 6.41 & 7.09 & 6.4 & 6.88 & 6.51 & & \\
\hline Sulama Suyu Sınıfı & $\mathrm{T} 2 \mathrm{Al}$ & $\mathrm{T} 2 \mathrm{Al}$ & $\mathrm{T} 2 \mathrm{Al}$ & $\mathrm{T} 2 \mathrm{Al}$ & T1Al & & \\
\hline TDS (mg L-1) & 172 & 226 & 206 & 164 & 146 & I & 1 \\
\hline ORP (mV) & 44.8 & 34.6 & 21.7 & 40.2 & 94.8 & & \\
\hline \multicolumn{8}{|c|}{ Oksitlendirme Parametreleri } \\
\hline $\mathrm{BOI}\left(\mathrm{mg} \mathrm{L}^{-1}\right)$ & - & - & - & - & - & & \\
\hline $\mathrm{KOI}\left(\mathrm{mg} \mathrm{L}^{-1}\right)$ & - & - & - & - & - & & \\
\hline \multicolumn{8}{|c|}{ Bakteriyolojik Parametreler (CFU/100 ml) } \\
\hline Toplam Koliform & 50 & 920 & 245 & 250 & 791 & & \\
\hline Fekal Koliform & 5 & 20 & 45 & 56 & 56 & & \\
\hline \multicolumn{8}{|c|}{ Besin Elementleri (Nutrient Parametreleri } \\
\hline $\mathrm{NH}_{4}-\mathrm{N}\left(\mathrm{mg} \mathrm{L}^{-1}\right)$ & 7.78 & 2.88 & 3.59 & 0.26 & - & & \\
\hline $\mathrm{NO}_{3}-\mathrm{N}\left(\mathrm{mg} \mathrm{L}^{-1}\right)$ & 2.23 & 2.08 & 2.08 & - & 2.09 & & I \\
\hline$P\left(\mu g L^{-1}\right)$ & - & - & - & - & - & & \\
\hline \multicolumn{8}{|c|}{ İz Elementler (Metal) ve İnorganik Parametreler } \\
\hline Alüminyum ( $\left.\mu \mathrm{g} \mathrm{Al} \mathrm{L}^{-1}\right)$ & 20.0 & 48.7 & 165.8 & 284.2 & 120.6 & & \\
\hline Arsenik ( $\mu g$ As L L $\left.^{-1}\right)$ & - & 0.89 & 0.75 & 1.37 & 2.5 & & \\
\hline Bakır ( $\left.\mu g \mathrm{Cu} \mathrm{L}^{-1}\right)$ & - & - & 1.3 & 2.8 & 11.6 & & \\
\hline Bor $\left(\mu g B^{-1}\right)$ & - & 11.1 & 24.2 & - & 13.8 & I & I \\
\hline Civa ( $\left.\mu g \mathrm{Hg} \mathrm{L}^{-1}\right)$ & - & - & - & - & - & & \\
\hline Çinko ( $\left.\mu g \mathrm{Zn} \mathrm{L}{ }^{-1}\right)$ & - & - & - & 56.1 & 19.1 & & \\
\hline Demir ( $\mu \mathrm{g} \mathrm{Fe} \mathrm{L^{-1 } )}$ & - & 20.4 & 240.5 & 263.8 & 79.2 & & \\
\hline Florür ( $\left.\mu \mathrm{g} F \mathrm{~L}^{-1}\right)$ & - & - & - & - & - & & \\
\hline Kadmiyum ( $\left.\mu \mathrm{g} C \mathrm{Cl}^{-1}\right)$ & - & - & - & - & - & & \\
\hline 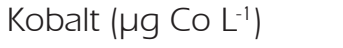 & - & - & - & - & - & & \\
\hline Krom ( $\mu \mathrm{g} \mathrm{Cr} \mathrm{L-1)}$ & - & - & - & - & - & & \\
\hline Kurșun ( $\left.\mu \mathrm{g} \mathrm{Pb} \mathrm{L}^{-1}\right)$ & - & - & - & - & - & & \\
\hline Mangan ( $\left.\mu \mathrm{g} M n \mathrm{~L}^{-1}\right)$ & - & 8.1 & 40.1 & 25.0 & 70.8 & & \\
\hline Nikel ( $\left.\mu g \mathrm{Ni} \mathrm{L}^{-1}\right)$ & - & - & - & - & - & & \\
\hline 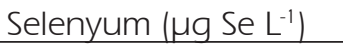 & - & - & - & - & - & & \\
\hline KYSKK & III & II & ॥ & ॥ & ॥ & & \\
\hline
\end{tabular}

KYSKK: Kıtaiçi Yerüstü Su Kaynaklarının Sınıflarına Göre Kalite Kriterleri, SSKK: Sulama Suyunun Kimyasal Kalitesi RSC: Artık Sodyum Karbonat, ORP: Oksidasyon-Redüksiyon Potansiyeli, TDS: Toplam Çözünmüș lyonlar, *Yağmurlama sulama "-“ Yok

\begin{tabular}{|l|l|l|l|l|l|l|l|}
\hline I.Sinıf & & II.Sinıf & & III.Sinıf & & IV.Sinıf \\
\hline
\end{tabular}


$\mathrm{pH}$ değerleri kıtaiçi yer üstü su kaynaklarının sınıflamasına göre sadece Haziran ayında 8.5 değerini așarak III. sınıfta yer almıștır. FAO29'a göre ise $\mathrm{pH}$ için normal aralık 6.5-8.4'tür. Bu kritere göre Süloğlu barajı suyu Haziran, Temmuz ve Ağustos aylarında söz konusu değerin bir miktar üzerinde bulunmuștur. Arat (2014) tarafindan, baraj suyu elektriksel iletkenlik değerlerinin $221 \mu \mathrm{cm}^{-1}$ ila $339 \mu \mathrm{S} \mathrm{cm} \mathrm{cm}^{-1}, \mathrm{pH}$ değerlerinin 7.87 ile 8.48 arasında değiștiği belirlenmiștir. Aydoğan vd. (2019) Ekim ve Mayıs aylarında Süloğlu barajından aldıkları su örneklerinde $\mathrm{pH}$ değerlerinin 7.99 ve 8.12,

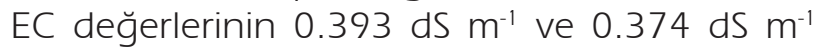
olduğunu tespit etmișlerdir.

Baraj suyunun besin elementleri parametrelerine bakıldığında $\left(\mathrm{HN}^{+}{ }_{4}-\mathrm{N}, \mathrm{NO}_{3}^{-}-\mathrm{N}\right.$, P) kıtaiçi yerüstü su kaynakları sınıflamasında I. sınıfta yer aldığı, sadece Haziran ayında amonyum azotunun yükselerek suyun II. sınıfta yer almasına neden olduğu görülmektedir. Baraj suyunda Tokatlı (2018) $1.21 \mathrm{mg} \mathrm{L}^{-1}$ ila $1.29 \mathrm{mg} \mathrm{L}^{-1}$ arasında $\mathrm{NO}_{3}$ belirlerken, Arat (2014)'ın belirlediği en yüksek $\mathrm{NO}_{3}-\mathrm{N}$ değeri 3.6 mg L ${ }^{-1}$ olmuștur. Yürütülen çalıșmada beș ay boyunca P parametresine rastlanmazken, Tokatlı (2018) $0.076 \mathrm{mg} \mathrm{L}^{-1}$ ile $0.078 \mathrm{mg} \mathrm{L}^{-1}$ arasında $P$ belirlemiștir. Arat (2014) ilkbahar ve yaz aylarında 0-0.02 $\mathrm{mg} \mathrm{L}^{-1}$ arasında $P$ tespit etmiș olup en yüksek $P$ değerini $\left(0.18 \mathrm{mg} \mathrm{L}^{-1}\right)$ sonbaharda belirlemiștir. Bakteriyolojik parametreler (toplam ve fekal koliform) açısından baraj suyu II. sınıfta yer almıștır. Baraj suyunda oksitlendirme parametrelerine (BOI ve $\mathrm{KOI})$ rastlanmazken, Tokatlı (2018) tarafından yürütülen çalıșmada, BOi değerleri 9.2 ile 7.3 arasında, KOi değerleri 37.7 ile 29.1 arasında bulunmuștur.

İz elementleri (metaller) ve inorganik kirlilik parametreleri $(\mathrm{Al}, \mathrm{As}, \mathrm{Cu}, \mathrm{B}, \mathrm{Hg}, \mathrm{Zn}, \mathrm{Fe}$, $\mathrm{F}, \mathrm{Cd}, \mathrm{Co}, \mathrm{Cr}, \mathrm{Pb}, \mathrm{Mn}, \mathrm{Ni}$ ve Sel açısından değerlendirildiğinde baraj suyu tüm aylarda I. (sulamada kullanılmasında herhangi bir sakınca yoktur) sınıf su kalitesinde yer almıștır.

Altınyazı baraj sularının kalite parametreleri Çizelge 3'te verilmiștir. Çizelgede yer alan verilere göre; baraj suyu, sulama suyu açısından $T_{2} A_{1}$ sınıfında yer almıștır. Bu sınıflamaya göre T2-orta tuzlu su ve $A_{1}$-az sodyumlu su sinıfinda yer almıștır. Elektriksel iletkenlik değerleri (dS $\mathrm{m}_{-1}$ ) su kirliliği kontrol yönetmeliğinde yer alan kıtaiçi yerüstü su kaynaklarının sınıflarına göre kalite kriterleri sınıflamasına göre değerlendirildiğinde beș ay boyunca baraj suyu II. sınıfta (iyi) yer almıștır. Baraj suyunun sulama mevsimi boyunca gerek Atıksu Arıtma Tesisleri Teknik Usuller Tebliğindeki sulama suyunun kimyasal kalitesinin değerlendirilmesi kriterlerine göre, gerek FAO-29 sınıflamasına göre sulama suyu olarak kullanıma uygun olduğu ortaya çıkmıștır.

Diğer parametreler açısından değerlendirildiğinde;

oksitlendirme parametreleri yönünden sorun görülmezken, sularda toplam koliform ve fekal koliform tespit edilmiș ve değerlerler I. ve II. sınıf arasında, yani "iyi" su sınıfında yer almıștır. Besin elementleri ve iz elementleri ile inorganik parametrelerinde sadece Eylül ayında Fe değerlerinde bir miktar artıș olduğu (II. sınıf) tespit edilmiștir. Tokatlı (2018)'ya göre de baraj suyunun $\mathrm{EC}, \mathrm{PO}_{4}$ ve $\mathrm{BO}$ parametreleri II. sınıfta, fekal koliform değerleri IIIII. ve $\mathrm{pH}, \mathrm{TDS}, \mathrm{NO}_{3}$ ve KOI değerleri I. sınıfta yer almaktadır. Çetin (2013) Altınyazı baraj suyunda yaptığı ağır metal analizlerinde Fe dıșında ağır metal tespit etmezken, sedimentte $\mathrm{Cd}, \mathrm{Cr}$, Zn, $\mathrm{Cu}, \mathrm{Fe}, \mathrm{Mn}$ ve $\mathrm{Pb}$ belirlenmiș olup bulunan değerler limit değerlerinin altında kalmıștır.

Sultanköy barajından Haziran-Ekim 2016 tarihleri arasında yapılan su örneklemeleri (Çizelge 4) $T_{2} A_{1}$ sulama suyu sınıfında yer almıștır. Su kirliliği kontrol yönetmeliğinde yer alan KYSKK'ya göre $\mathrm{pH}$ değerleri Haziran, Temmuz ve Eylül aylarında 8.5 değerini bir miktar așarak II. ile III. arasında "orta" su sınıfında yer almıștır. Sularda BOi ve KOI parametrelerine rastlanmazken, toplam ve fekal koliform tespit edilmiș olup belirlenen değerlere göre baraj suyu "iyi" su niteliğindedir.

Besin elementleri, amonyum ve nitrat açısından suda herhangi bir kirlilik belirlenmemiș, fakat Ağustos, Eylül ve Ekim aylarında fosfor değerlerinde meydana gelen yükselmeler nedeniyle sular II. sınıfta yer almıștır. Kıtaiçi yer üstü su kaynaklarının sınıflamasına göre II. sınıf sular, mer'i mevzuat ile tespit edilmiș olan sulama suyu kalite kriterlerini sağlamak șartıyla sulama suyu olarak tanımlanmıștır. Bir bașka çalıșmada baraj suyunda fekal koliform (III-III. sınıf), BOI (III. sınıf) ve $\mathrm{NO}_{2}$ (IV. sınıf) kirliliği belirlenirken, baraj suyu tuzluluk, $\mathrm{PO}_{4}$ ve $\mathrm{KOI}$ açısından II. sınıfta yer almıștır (Tokatlı, 2018). 
Çizelge 3. Altınyazı barajı aylık analiz sonuçları

Table 3. Altınyazı dam monthly analysis results

\begin{tabular}{|c|c|c|c|c|c|c|c|}
\hline Parametreler & $\begin{array}{c}\text { Haziran } \\
2016\end{array}$ & $\begin{array}{c}\text { Temmuz } \\
2016\end{array}$ & $\begin{array}{c}\text { Ağustos } \\
2016\end{array}$ & Eylül 2016 & $\begin{array}{l}\text { Ekim } \\
2016\end{array}$ & SSKK & FAO-29 \\
\hline $\mathrm{pH}$ & 8.43 & 8.38 & 8.26 & 8.41 & 8.4 & & \\
\hline İletkenlik (dS m-1) & 0.69 & 0.683 & 0.665 & 0.675 & 0.637 & I & I \\
\hline $\mathrm{CO}_{3}^{-2}\left(\mathrm{me} \mathrm{L}^{-1}\right)$ & 0.9 & 1.0 & 0.99 & 0.99 & 1.19 & & \\
\hline $\mathrm{HCO}_{3}-\left(\mathrm{me} \mathrm{L}^{-1}\right)$ & 4.13 & 4.01 & 3.99 & 4.12 & 4.06 & & $\|^{*}$ \\
\hline $\mathrm{Cl}-\left(\mathrm{me} \mathrm{L}^{-1}\right)$ & 1.38 & 1.02 & 1.3 & 1.2 & 1.45 & I & । \\
\hline $\mathrm{Na}^{+}\left(\mathrm{me} \mathrm{L}^{-1}\right)$ & 2.5 & 2.32 & 2.37 & 2.56 & 2.45 & । & I \\
\hline $\mathrm{Mg}^{+2}\left(\mathrm{me} \mathrm{L}^{-1}\right)$ & 3.35 & 3.38 & 3.43 & 3.35 & 3.18 & & \\
\hline $\mathrm{K}+\left(\mathrm{me} \mathrm{L}^{-1}\right)$ & 0.15 & 0.11 & 0.13 & 0.14 & 0.14 & & \\
\hline $\mathrm{Ca}^{+2}\left(\mathrm{me} \mathrm{L}^{-1}\right)$ & 2.59 & 2.25 & 2.33 & 2.31 & 2.15 & & \\
\hline SAR & 1.45 & 1.39 & 1.4 & 1.52 & 1.51 & I & I \\
\hline $\mathrm{SO}_{4}\left(\mathrm{me} \mathrm{L}^{-1}\right)$ & 2.18 & 2.03 & 1.98 & 2.05 & 1.22 & & \\
\hline RSC & - & - & - & - & - & & \\
\hline Sertlik (Alman) & 16.65 & 15.76 & 16.15 & 15.85 & 14.92 & & \\
\hline Sulama Suyu Sınıfı & $\mathrm{T} 2 \mathrm{~A} 1$ & $\mathrm{~T} 2 \mathrm{~A} 1$ & $\mathrm{~T} 2 \mathrm{~A} 1$ & $\mathrm{~T} 2 \mathrm{~A} 1$ & $\mathrm{~T} 2 \mathrm{Al}$ & & \\
\hline $\operatorname{TDS}\left(\mathrm{mg} \mathrm{L}^{-1}\right)$ & 433 & 443 & 416 & 424 & 409 & I & I \\
\hline ORP (mV) & 28.3 & 34.5 & -40.7 & 91.1 & 32.3 & & \\
\hline
\end{tabular}

Oksitlendirme Parametreleri

BOi (mg L-1)

$\mathrm{KOI}\left(\mathrm{mg} \mathrm{L}^{-1}\right)$

Bakteriyolojik Parametreler (CFU/100 ml)

\begin{tabular}{|c|c|c|c|c|c|c|}
\hline Toplam Koliform & 1635 & 1152 & 1150 & 850 & 1624 & \\
\hline Fekal Koliform & 92 & 17 & 75 & 64 & 152 & \\
\hline \multicolumn{7}{|c|}{ Besin Elementleri (Nutrient) Parametreleri } \\
\hline $\mathrm{NH}_{4}-\mathrm{N}\left(\mathrm{mg} \mathrm{L}^{-1}\right)$ & - & 0.78 & 0.7 & 3.14 & 2 & \\
\hline $\mathrm{NO}_{3}^{4}-\mathrm{N}\left(\mathrm{mg} \mathrm{L}^{-1}\right)$ & 4.83 & 4.45 & 4.46 & 4.4 & 4.14 & I \\
\hline Fosfor $\left(\mu \mathrm{q}^{-1}\right)$ & 23.51 & 16.69 & 20.46 & 29.68 & 11.66 & \\
\hline
\end{tabular}

iz Elementler (Metal) ve İnorganik Parametrele

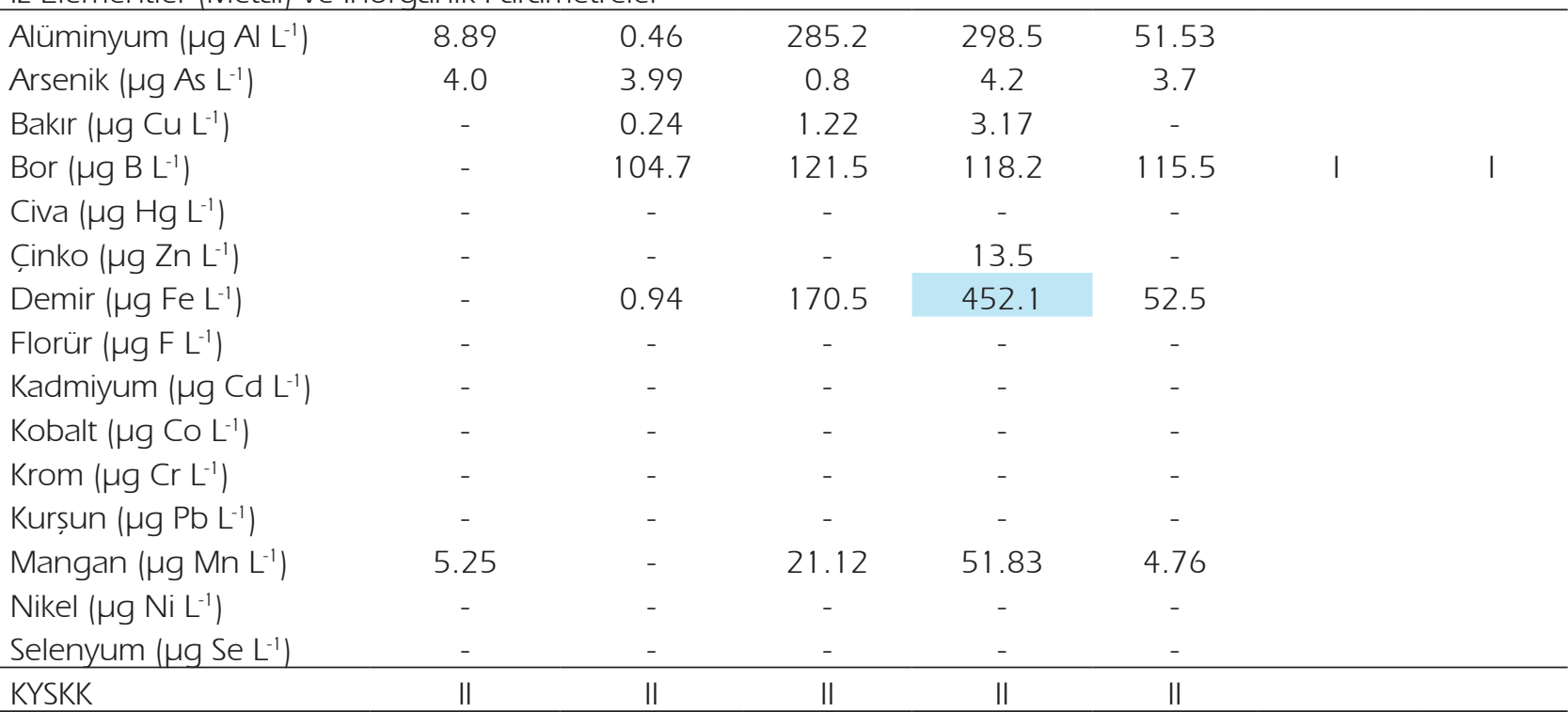

KYSKK: Kıtaiçi Yerüstü Su Kaynaklarının Sınıflarına Göre Kalite Kriterleri, SSKK: Sulama Suyunun Kimyasal Kalitesi RSC: Artık Sodyum Karbonat, ORP: Oksidasyon-Redüksiyon Potansiyeli, TDS: Toplam Çözünmüș lyonlar,

\begin{tabular}{|l|l|l|l|l|l|l|l|}
\hline & I.Sinıf & & II.Sinıf & & III.Sinif & & IV.Sinif \\
\hline
\end{tabular}


Çizelge 4. Sultanköy barajı aylık analiz sonuçları

Table 4. Sultanköy dam monthly analysis results

\begin{tabular}{|c|c|c|c|c|c|c|c|}
\hline Parametreler & $\begin{array}{c}\text { Haziran } \\
2016 \\
\end{array}$ & $\begin{array}{c}\text { Temmuz } \\
2016 \\
\end{array}$ & $\begin{array}{c}\text { Ağustos } \\
2016\end{array}$ & Eylül 2016 & $\begin{array}{l}\text { Ekim } \\
2016\end{array}$ & SSKK & FAO-29 \\
\hline $\mathrm{pH}$ & 8.54 & 8.54 & 8.06 & 8.04 & 8.66 & & \\
\hline İletkenlik (dS m-1) & 0.624 & 0.626 & 0.591 & 0.598 & 0.551 & I & I \\
\hline $\mathrm{CO}_{3}^{-2}\left(\mathrm{me} \mathrm{L}^{-1}\right)$ & 0.92 & 0.82 & 0.83 & 0.58 & 1.04 & & \\
\hline $\mathrm{HCO}_{3}^{-}\left(\mathrm{me} \mathrm{L}^{-1}\right)$ & 3.26 & 2.98 & 3.1 & 2.95 & 3.11 & & $\|^{*}$ \\
\hline $\mathrm{Cl}^{-}\left(\mathrm{me} \mathrm{L}^{-1}\right)$ & 2.15 & 2.25 & 2.35 & 2.7 & 2.6 & I & I \\
\hline $\mathrm{Na}^{+}\left(\mathrm{me} \mathrm{L}^{-1}\right)$ & 2.63 & 2.48 & 2.53 & 2.8 & 2.56 & I & I \\
\hline $\mathrm{Mg}^{+2}\left(\mathrm{me} \mathrm{L}^{-1}\right)$ & 2.04 & 1.93 & 2.03 & 2.08 & 1.87 & & \\
\hline $\mathrm{K}^{+}\left(\mathrm{me} \mathrm{L}^{-1}\right)$ & 0.13 & 0.13 & 0.15 & 0.15 & 0.12 & & \\
\hline $\mathrm{Ca}^{+2}\left(\mathrm{me} \mathrm{L}^{-1}\right)$ & 2.45 & 2.68 & 2.6 & 2.46 & 3.13 & & \\
\hline SAR & 1.75 & 2.64 & 1.67 & 1.86 & 1.81 & I & I \\
\hline $\mathrm{SO}_{4}\left(\mathrm{me} \mathrm{L}^{-1}\right)$ & 0,92 & 1,17 & 1,03 & 1,26 & 0,93 & & \\
\hline RSC & - & - & - & - & - & & \\
\hline Sertlik (Alman) & 12.6 & 12.91 & 12.96 & 12.74 & 11.21 & & \\
\hline Sulama Suyu Sınıfı & $\mathrm{T} 2 \mathrm{Al}$ & $\mathrm{T} 2 \mathrm{~A} 1$ & $\mathrm{~T} 2 \mathrm{Al}$ & $\mathrm{T} 2 \mathrm{Al}$ & $\mathrm{T} 2 \mathrm{Al}$ & & \\
\hline TDS $\left(\mathrm{mg} \mathrm{L}^{-1}\right)$ & 426 & 392 & 380 & 364 & 356 & I & I \\
\hline ORP (mV) & 91.2 & 55.3 & 27.4 & 88.2 & 66.0 & & \\
\hline
\end{tabular}

Oksitlendirme Parametreleri

BOi $\left(\mathrm{mg} \mathrm{L}^{-1}\right)$

$\mathrm{KOI}\left(\mathrm{mg} \mathrm{L}^{-1}\right)$

Bakteriyolojik Parametreler (CFU/100 ml)

$\begin{array}{llllll}\text { Toplam Koliform } & 285 & 1960 & 1450 & 1700 & 5115\end{array}$

Fekal Koliform

20

40

90

95

180

Besin Elementleri (Nutrient) Parametreleri

\begin{tabular}{llcccc}
\hline $\mathrm{NH}_{4}-\mathrm{N}\left(\mathrm{mg} \mathrm{L}^{-1}\right)$ & 1.01 & - & - & - & 3.5 \\
$\mathrm{NO}_{3}-\mathrm{N}\left(\mathrm{mg} \mathrm{L}^{-1}\right)$ & 4.46 & 4.27 & 2.21 & 4.63 & -
\end{tabular}

Fosfor $\left(\mu \mathrm{g} \mathrm{L}^{-1}\right)$ 17.24

67.79
69.22 68.66

iz Elementler (Metal) ve İnorganik Parametreler

\begin{tabular}{|c|c|c|c|c|c|c|c|}
\hline Alüminyum ( $\left.\mu \mathrm{g} \mathrm{Al} \mathrm{L}^{-1}\right)$ & 9.95 & - & 272.1 & 221.19 & 38.92 & & \\
\hline Arsenik ( $\mu g$ As L L $\left.^{-1}\right)$ & 6.6 & 0.2 & 1.7 & 1.2 & 5.6 & & \\
\hline Bakır ( $\left.\mu g \mathrm{Cu} \mathrm{L}^{-1}\right)$ & - & 1.0 & 3.5 & 1.8 & - & & \\
\hline Bor $\left(\mu g B^{-1}\right)$ & - & 61.38 & 75.65 & 64.62 & 66.53 & I & I \\
\hline Civa ( $\left.\mu g \mathrm{Hg} \mathrm{L}^{-1}\right)$ & - & - & - & - & - & & \\
\hline 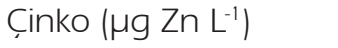 & - & - & - & 13.35 & 11.04 & & \\
\hline Demir ( $\left.\mu \mathrm{g} \mathrm{Fe} \mathrm{L}{ }^{-1}\right)$ & - & 39.73 & 916.5 & 602.22 & 24.88 & & \\
\hline Florür ( $\mu g \mathrm{~F} \mathrm{~L}^{-1}$ ) & - & - & - & - & - & & \\
\hline Kadmiyum ( $\left.\mu \mathrm{g} \mathrm{Cd} \mathrm{L}^{-1}\right)$ & - & - & - & - & - & & \\
\hline 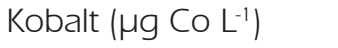 & - & - & - & - & - & & \\
\hline Krom ( $\left.\mu g \mathrm{Cr} \mathrm{L}^{-1}\right)$ & - & - & - & - & - & & \\
\hline Kurșun ( $\mu \mathrm{g}$ Pb L-1) & - & - & - & - & - & & \\
\hline Mangan ( $\mu g \mathrm{Mn} \mathrm{L}^{-1}$ ) & - & - & 21.07 & 57.69 & 3.36 & & \\
\hline Nikel ( $\left.\mu g \mathrm{Ni} \mathrm{L}^{-1}\right)$ & - & - & - & - & - & & \\
\hline 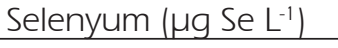 & - & - & - & - & - & & \\
\hline KYSKK & III & III & ॥ & II & III & & \\
\hline
\end{tabular}
KYSKK: Kıtaiçi Yerüstü Su Kaynaklarının Sınıflarına Göre Kalite Kriterleri, SSKK: Sulama Suyunun Kimyasal Kalitesi RSC: Artık Sodyum Karbonat, ORP: Oksidasyon-Redüksiyon Potansiyeli, TDS: Toplam Çözünmüș lyonlar, *Yağmurlama sulama, "-“ Yok

\begin{tabular}{|l|l|l|l|l|l|l|l|}
\hline & I.Sinıf & & II.Sinıf & & III.Sinıf & & IV.Sinıf \\
\hline
\end{tabular}


İz elementleri (metaller) ve inorganik kirlilik parametreleri (Al, As, Cu, B, Hg, Zn, $\mathrm{Fe}, \mathrm{F}, \mathrm{Cd}, \mathrm{Co}, \mathrm{Cr}, \mathrm{Pb}, \mathrm{Mn}, \mathrm{Ni}$ ve Sel açısından değerlendirildiğinde baraj suyu birçok parametre yönünden I. sınıf su kalitesinde yer alırken, Ağustos ve Eylül aylarında Al ve Fe parametrelerindeki yükselme ile II. sınıfta yer almıștır.

Hamzadere barajı, temel parametreler açısından değerlendirildiğinde elektriksel iletkenlik değerinin $0.75 \mathrm{dS} \mathrm{m}^{-1}$ değerini așması ile $T_{3}$ sınıfında yer almıștır (Çizelge 5). $T_{3}$ sınıfında yer alan sular daha kontrollü drenaj koșullarında ve yetiștirilecek bitkinin tuza dayanımı dikkate alınarak kullanılması gereken sulardır. Bunun yanı sıra su kirliliği kontrol yönetmeliğinde yer alan kıtaiçi yerüstü su kaynaklarının sınıflarına göre kalite kriterleri sınıflamasına göre beș ay boyunca baraj suyu, EC açısından II. sınıfta (iyi) yer almaktadır. pH değerleri Haziran ve Temmuz aylarında 8.5 değerini așmıștır. Bakteriyolojik yönden baraj suyu II. sınıfta yer almıștır.

Besin elementleri açısından değerlendirme yaptığımızda; Haziran, Temmuz, Ağustos ve Eylül aylarında amonyum değerleri yönünden sular I. sınıfta yer alırken Ekim ayında değer yükselmiș ve II. sınıfta yer almıștır. Nitrat açısından sıkıntı görülmezken, fosfor değerlerinde Ağustos ve Ekim aylarında yükselme gözlenmiș ve su II. sınıf su kalitesinde yer almıștır.

Hamzadere barajının inorganik parametrelerine ve iz elementlerine baktığımızda (Çizelge 5), sadece $\mathrm{Mn}$ değerlerinin Ağustos ve Ekim aylarında yükseldiğini görüyoruz. Bu yükselme ile baraj suyu, II. su kalite sınıfında yer almaktadır.

Baraj suyu SSKK (Sulama Suyunun Kimyasal Kalitesi) kriterlerine göre kullanımında zarar derecesi az-orta olan II. sınıfta yer almaktadır. FAO-29 kriterlerine göre baraj suyunun kullanım kısıtlama derecesi "hafif-orta” dır.

Trakya bölgesi ülke tarım potansiyelinde önemli bir yere sahiptir. Bölgede en çok ekilen ürünler buğday, ayçiçeği ve çeltiktir. Edirne ilinde çeltik üretimi ülke genelinin \%40'ını olușturmaktadır (Anonim, 2011). Aydoğan (2014)'nın bildirdiğine göre Ülkemizde tüketilen toplam azotlu gübre sıralamasında Edirne ili 10. sırada yer almaktadır. Çeltik üretiminde diğer ürünlere kıyasla daha fazla su ve daha fazla gübre ile pestisit kullanılmaktadır.

Yoğun gübre ve pestisit kullanımı toprak ve su kaynaklarının kirlenmesine neden olmaktadır. Su kalitesinin bozulması ve kalitesi düșük suların sulama amaçlı kullanılması sadece ürün miktarına ve kalitesine zarar vermekle kalmayıp zaman içerisinde toprakların da tuzlulașmasına ve alkalileșmesine neden olmaktadır. Su kalitesi özellikle çeltik ekim alanlarında münavebenin de söz konusu olmaması ve olușturulan su yükü ile toprak yapısının daha fazla zarar görmesi ile su kalitesi faktörü daha da büyük önem arz etmektedir.

İncelenen barajlardan üçü (Altınyazı, Sultanköy ve Hamzadere) Edirne ilinin güney kısmında yer almakta olup, çeltik ekiminin yoğun yapıldığı bölgededir. Tuzluluk ve alkalilik sulama suyu sınıflamasında iki önemli parametre olup elde edilen sonuçlara göre; Süloğlu, Altınyazı ve Sultanköy barajlarında sorun görülmezken, Hamzadere baraj suyu EC değerleri 0.797 dS $\mathrm{m}^{-1}$ ile $0.956 \mathrm{dS} \mathrm{m}^{-1}$ arasında tespit edilmiștir. Söz konusu barajın yer aldığı konumda yoğun sulu tarım yapılmaktadır. Dolayısıyla sulamadan dönen kuyruk suları ve Meriç nehrinden pompajla su takviyesi baraj suyunun tuzluluk seviyesini etkilemektedir.

Oksitlendirme parametreleri açısından dört barajda da sorun görülmezken, amonyum düzeyi Süloğlu barajında Haziran ayında, Hamzadere barajında ise Ekim ayında II. sınıf su kalitesinde yer almıștır. Fosfor Sultanköy ve Hamzadere barajlarında bazı aylarda tespit edilmiș olup değerler II. sınıf limit değerlerini așmamıștır. Bakteriyolojik parametreler açısından barajlarda önemli derecede sorun belirlenmemiș olsa da tam anlamıla çevrelerindeki insan ve hayvan faaliyetleri ile tarımsal faaliyetlerden etkilenmediği söylenemez. Zira dört barajda da sular bakteriyolojik parametreler yönünden II. sınıfta yer almıștır.

Altınyazı, Sultanköy ve Hamzadere baraj suları irdelenen bazı iz elementleri ve inorganik parametreler (P, Al, Fe ve Mn) açısından zaman zaman II. sınıfta yer alsa da sulama sularında izin verilen maksimum ağır metal ve toksik element değerlerini așmadığından sulamaya uygun sular sınıfında yer almıșlardır. 
Çizelge 5. Hamzadere barajı aylık analiz sonuçları

Table 5. Hamzadere dam monthly analysis results

\begin{tabular}{|c|c|c|c|c|c|c|c|}
\hline Parametreler & Haziran & Temmuz & Ağustos & Eylül & Ekim & SSKK & FAO-29 \\
\hline $\mathrm{pH}$ & 8.63 & 8.78 & 8.25 & 8.34 & 8.46 & \multirow{4}{*}{$\|$} & \multirow{3}{*}{$\|$} \\
\hline İletkenlik (dS $\mathrm{m}^{-1}$ ) & 0.956 & 0.911 & 0.847 & 0.797 & 0.883 & & \\
\hline $\mathrm{CO}_{3}^{-2}\left(\mathrm{me} \mathrm{L}^{-1}\right)$ & 1.2 & 0.95 & 0.76 & 1.15 & 1.09 & & \\
\hline $\mathrm{HCO}_{3}^{-}\left(\mathrm{me} \mathrm{L}^{-1}\right)$ & 3.96 & 2.88 & 3.05 & 2.9 & 3.08 & & ॥ \\
\hline $\mathrm{Cl}^{-}\left(\mathrm{me} \mathrm{L}^{-1}\right)$ & 4.58 & 4.52 & 4.8 & 4.55 & 4.5 & \multirow{2}{*}{$\begin{array}{l}\| \\
\|\end{array}$} & ॥ \\
\hline $\mathrm{Na}^{+}\left(\mathrm{me} \mathrm{L}^{-1}\right)$ & 4.9 & 4.57 & 4.59 & 4.82 & 4.54 & & $\|$ \\
\hline $\mathrm{Mg}^{+2}\left(\mathrm{me} \mathrm{L}^{-1}\right)$ & 2.54 & 2.3 & 2.45 & 2.31 & 2.16 & \multirow{7}{*}{ I } & \multirow{7}{*}{ I } \\
\hline $\mathrm{K}^{+}\left(\mathrm{me} \mathrm{L}^{-1}\right)$ & 0.12 & 0.11 & 0.13 & 0.13 & 0.12 & & \\
\hline $\mathrm{Ca}^{+2}\left(\mathrm{me} \mathrm{L}^{-1}\right)$ & 2.6 & 2.39 & 2.99 & 2.35 & 2.29 & & \\
\hline SAR & 3.05 & 2.99 & 2.78 & 3.16 & 3.04 & & \\
\hline $\mathrm{SO}_{4}\left(\mathrm{me} \mathrm{L}^{-1}\right)$ & 0,42 & 1,02 & 1,55 & 1,01 & 0,44 & & \\
\hline RSC & - & - & - & - & - & & \\
\hline Sertlik (Alman) & 14.4 & 13.15 & 15.24 & 13.06 & 12.46 & & \\
\hline Sulama Suyu Sınıfı & T3A1 & T3Al & T3A1 & T3A 1 & T3A 1 & \multirow{3}{*}{ II } & \multirow{3}{*}{$\|$} \\
\hline $\operatorname{TDS}\left(\mathrm{mg} \mathrm{L}^{-1}\right)$ & 587 & 588 & 546 & 492 & 549 & & \\
\hline ORP (mV) & 142.4 & 71.3 & 30 & 65.8 & 83.2 & & \\
\hline
\end{tabular}

Oksitlendirme Parametreleri

BOi (mg L-1)

$\mathrm{KOI}\left(\mathrm{mg} \mathrm{L}^{-1}\right)$

Bakteriyolojik Parametreler (CFU/100 ml)

\begin{tabular}{|c|c|c|c|c|c|c|c|}
\hline Toplam Koliform & 700 & 600 & 1350 & 770 & 1466 & & \\
\hline Fekal Koliform & 35 & 30 & 80 & 105 & 123 & & \\
\hline \multicolumn{8}{|c|}{ Nutrient (Besin Elementleri) Parametreleri } \\
\hline $\mathrm{NH}_{4}-\mathrm{N}\left(\mathrm{mg} \mathrm{L}^{-1}\right)$ & 0.95 & 1.41 & - & 3.73 & 9.95 & & \multirow{3}{*}{$\|$} \\
\hline $\mathrm{NO}_{3}-\mathrm{N}\left(\mathrm{mg} \mathrm{L}^{-1}\right)$ & 4.16 & 4.27 & 4.21 & - & 4.14 & & \\
\hline Fosfor $\left(\mu g \mathrm{~L}^{-1}\right)$ & 20.7 & 20.1 & 68.89 & 8.6 & 48.6 & & \\
\hline \multicolumn{8}{|c|}{ İz Elementler (Metal) ve İnorganik Parametreler } \\
\hline Alüminyum ( $\mu \mathrm{g} \mathrm{Al} \mathrm{L-1)}$ & 1.4 & 31.8 & 145.6 & 118.5 & 88.6 & & \\
\hline Arsenik ( $\mu g$ As $\left.L^{-1}\right)$ & - & 0.8 & 0.8 & 0.3 & 0.9 & & \\
\hline Bakır ( $\mu g$ Cu L-1) & - & - & 1.6 & 3.5 & - & & \\
\hline Bor $\left(\mu g B^{-1}\right)$ & - & 94.3 & 109.3 & 94.4 & 96.4 & I & । \\
\hline Civa ( $\left.\mu g \mathrm{Hg} \mathrm{L}^{-1}\right)$ & - & - & - & - & - & & \\
\hline Çinko $\left(\mu g\right.$ Zn L $\left.{ }^{-1}\right)$ & - & - & - & 3.6 & 20.2 & & \\
\hline Demir $\left(\mu \mathrm{g} F e \mathrm{~L}^{-1}\right)$ & - & 21.8 & 198.3 & 162.8 & 65.4 & & \\
\hline Florür $\left(\mu g \mathrm{~F} \mathrm{~L}^{-1}\right)$ & - & - & - & - & - & & \\
\hline Kadmiyum ( $\left.\mu \mathrm{g} \mathrm{Cd} \mathrm{L}^{-1}\right)$ & - & - & - & - & - & & \\
\hline Kobalt ( $\left.\mu g \mathrm{Co} \mathrm{L}^{-1}\right)$ & - & - & - & - & - & & \\
\hline Krom ( $\left.\mu g \mathrm{Cr} \mathrm{L}^{-1}\right)$ & - & - & - & - & - & & \\
\hline Kurșun ( $\left.\mu \mathrm{g} \mathrm{Pb} \mathrm{L}^{-1}\right)$ & - & - & - & - & - & & \\
\hline Mangan ( $\left.\mu g \mathrm{Mn} \mathrm{L}^{-1}\right)$ & - & - & 152.8 & 20.4 & 162.3 & & \\
\hline Nikel $\left(\mu g \mathrm{Ni}^{-1}\right)$ & - & - & - & - & - & & \\
\hline Selenyum ( $\mu \mathrm{g}$ Se L $\left.L^{-1}\right)$ & - & - & - & - & - & & \\
\hline KYSKK & III & III & $\|$ & $\|$ & II & & \\
\hline
\end{tabular}

KYSKK: Kıtaiçi Yerüstü Su Kaynaklarının Sınıflarına Göre Kalite Kriterleri, SSKK: Sulama Suyunun Kimyasal Kalitesi RSC: Artık Sodyum Karbonat, ORP: Oksidasyon-Redüksiyon Potansiyeli, TDS: Toplam Çözünmüș lyonlar, *Yağmurlama sulama “-“ Yok

\begin{tabular}{|l|l|l|l|l|l|l|l|}
\hline & I.Sinıf & & II.Sinıf & & III.Sinıf & & IV.Sinıf \\
\hline
\end{tabular}




\section{SONUÇLAR}

Sonuç olarak; Süloğlu, Altınyazı ve Sultanköy baraj sularının sulama amaçlı kullanılmasında herhangi bir sorun olmadığı, Hamzadere baraj suyunun da $T_{3}$ sınıfında yer alması ile suların daha kontrollü drenaj koșullarında ve yetiștirilecek bitkinin tuza dayanımı dikkate alınarak kullanıması gerektiği ortaya çıkmıștır.

Yoğun tarım yapılan Edirne ilinin sulama suyu kaynaklarının sürdürülebilirliğinin sağlanabilmesi için insan ve hayvan faaliyetleri ile gübre ve pestisit kullanımının daha kontrollü hale getirilmesi gerekmektedir.

\section{TEȘEKKÜR}

Bu makale, T.C. Tarım ve Orman Bakanlığı, Tarımsal Araștırmalar ve Politikalar Genel Müdürlüğü desteği ile Kırklareli Toprak Su ve Tarımsal Meteoroloji Araștırma Enstitüsü tarafından yürütülen "Trakya Bölgesi Su Kaynaklarının Kalitesinin ve Tarımsal Açıdan Kullanılabilirliğinin Belirlenmesi" projesinden veriler içermektedir.

\section{KAYNAKLAR}

Andrew DE, Clesceri LS, Greenberg AE (1995). Standard methods for examination of water \& wastewater. Amerikan Public Health Association, Washington, D.C, p. 3:1-106.

Anonim (2009). Su kirliliği kontrolü yönetmeliği numune alma ve analiz metotları tebliği. http://www.resmigazete. gov.tr/eskiler/2009/10/20091010-6.htm. Erișim Tarihi: 05.08.2019.

Anonim (2010). Atıksu arıtma tesisleri teknik usuller tebliği. http://www.resmigazete.gov.tr/ eskiler/2010/03/20100320-7.htm, p. 81, Erișim Tarihi: 05.08.2019.

Anonim (2015). Su kirliliği kontrol yönetmeliği, kıtaiçi yerüstü su kaynaklarının sınıflarına göre kalite kriterleri. http:// www.resmigazete.gov.tr/eskiler/2015/04/20150415-18. htm. Erișim Tarihi: 05.08.2019.

Anonim (2011). Ulusal hububat konsey raporu. http:// www.pdd.org.tr/libs/filemanager. Erișim Tarihi 05.08.2019.

Arat SM (2014). Süloğlu baraj Gölü'nde (Edirne) mikrosistin varlığının araștırılması. Yüksek lisans tezi, Trakya Üniversitesi, Fen Bilimleri Enstitüsü, Edirne.

Aydoğan F, Bellitürk K, Sağlam MT (2014). Edirne ilindeki bazı sulama suyu kaynaklarının tuzluluk ve ağır metal içeriklerinin tespiti. Journal of Tekirdağ Agricultural Faculty, 11 (2): 27-37.

Çakır R, Gidirișlioğlu A (1997). Düșük kaliteli sulama sularının vertisol toprakların özelliklerine ve ayçiçeği bitkisinin vejetatif gelișmesine etkileri. Kültürteknik Derneği 6. Kongresi Bildirileri, p. 460-468. 5-8 Haziran 1997, Uludağ, Bursa.
Çakır R, Gidirișlioğlu A, Tok HH, Avșar F, Ekinci H, Yüksel $O$ (1997). Kirli nehir suların entisol ordosuna ait toprağın bazı özelliklerine ve ayçiçeği bitkisinin gelișmesine etkileri. I. Trakya Toprak ve Gübre Sempozyumu Bildirileri, p. 183-190. 20-22 Ekim 1997, Tekirdağ.

Çebi Ü, Gidirișlioğolu A, Çakır R (2008). Ergene nehri ve kollarının evsel ve endüstriyel atık parametrelerinin belirlenmesi. T.C Tarım ve Köyișleri Bakanlığı Tarımsal Araștırmalar Genel Müdürlüğü. Atatürk Toprak ve Su Kaynakları Araștırma Enstitüsü Müdürlüğü Yayınları, Kırklareli.

Çetin E (2013). Altınyazı baraj gölü'nde (Edirne) yașayan balık türlerinde ağır metal birikimlerinin incelenmesi. Yüksek lisan tezi, Trakya Üniversitesi Fen Bilimleri Enstitüsü, Edirne.

DSi (2019). Toprak ve Su Kaynakları. http://www.dsi. gov.tr/toprak-ve-su-kaynaklari, Erișim Tarihi: 05.08.2019

FAO-29 (1994). Water quality for agriculture. Available: http://www.fao.org/3/T0234E/T0234E0 1.htm\#tab1. Erișim Tarihi: 05.08.2019

Gidirișlioğlu A, Çakır R, Tok HH, Ekinci H, Yüksel O (1996). Ergene Nehri ve kollarının evsel ve endüstriyel atıklarla kirlenmesi ve toprak üzerine etkileri. Toprak ve Su Kaynakları Araștırma Yıllığı, Ankara.

İstanbulluoğlu A, Konukçu F, Kocaman i (2006). Trakya Bbölgesi su kaynaklarının geliștirilmesi ve sulu tarım uygulamaları: mevcut verilerin sorunların çözümü için analizi. Tekirdağ Ziraat Fakültesi Dergisi, 3(2): 139-152.

Karaca Eroğlu E (2015). Süloğlu baraj gölü'nün (Edirne) bazı fizikokimyasal özellikleri ve bentik makrofaunasının incelenmesi. Yüksel Ilisans ttezi, Trakya Üniversitesi Fen Bilimleri Enstitüsü, Biyoloji Ana Bilim Dalı (Basılmamıș). Edirne.

Katkat G, Tok HH, Aydın M, Sağlam MT, Öner $N$, Kamburoğlu U (1997). Tekirdağ il sınırları dahilindeki içme suyu kuyularında bazı kirlilik parametrelerinin dağılımları ve zamanla değișimleri. I. Trakya Toprak ve Gübre Sempozyumu Bildiriler Kitabı, p. 289-295, 20-22 Ekim 1997, Tekirdağ.

Kaykıoğlu G, Ekmekyapar F (2005). Ergene havzasında endüstriyel ișlem suyu olarak kullanılan yeraltı sularının özellikleri üzerine bir araștırma. Trakya Üniversitesi Fen Bilimleri Dergisi, 6(1): 85-91.

Konukçu F, İstanbulluoğlu A, Orta AH, Kocaman i (2004). Trakya Bölgesi su kaynakları sorunları ve çözüm önerileri. İstanbul ve Su Sempozyumu. TMMOB Mimarlar Odası İstanbul Büyükkent Șubesi, p. 85-96, İstanbul.

Tokatlı C (2018). Water quality assesment of edirne dam lakes (wastern section of the Ergene river basiın). International 5th National Symposium on Dam Safety, p. 918-923, 27-31 October 2018, İstanbul, Turkey.

Tüzüner A (1990). Toprak ve su analiz laboratuvar el kitabı, Köy Hizmetleri Genel Müdürlüğü Yayınları, Ankara. 